\title{
Analysis of Conflict Resolution Strategies of Head Teachers: Teachers' Perspective
}

\author{
${ }^{a}$ Masood Ahmad, ${ }^{b}$ Toheed Qamar, ${ }^{c}$ Muhammad Tahir Nadeem, ${ }^{d}$ Muhammad Farooq Ahmad \\ ${ }^{a}$ Assistant Professor, Department of Education Training, The Islamia University of Bahawalpur, Punjab, Pakistan \\ Email: masood.ahmad@iub.edu.pk \\ ${ }^{\mathrm{b}}$ Subject Specialist (Edu.), QAED (M) Bahawalpur, Pakistan \\ Email: toheedphysicst@gmail.com \\ ${ }^{c}$ Assistant Professor, Department of Education, The Islamia University of Bahawalpur, Punjab, Pakistan \\ Email: tnadeem18o@gmail.com \\ d Subject Specialist, GHSS LalSohenra, Bahawalpur, Pakistan \\ Email: farooqmil786@gmail.com
}

\begin{tabular}{l}
\hline ARTICLE DETAILS \\
\hline History: \\
Accepted 26 August 2021 \\
Available Online September 2021 \\
\hline Keywords: \\
Conflict Resolution, Strategies, \\
Head Teachers, Teachers, \\
Secondary Level \\
\hline JEL Classification: \\
D74, A2O
\end{tabular}

DOI: $10.47067 /$ real.v4i3.184

\begin{abstract}
Conflict managing has become a center of gravity of human activities in these days. Head teachers should be well aware how to resolve conflict among staff members. So, the study was designed to analyze how head teachers can resolve conflict among staff members and was there any significance difference between male and female head teachers' conflict resolving strategies. Survey method was used to investigate conflict resolving strategies of the head teachers. Bahawalpur was the population of the study. Convenient sampling technique was used to select sample. Self-constructed instrument was applied to collect data. Questionnaire was consist of five types of parameters i-e integrating conflict, obliging conflict, dominating conflict, avoidance conflict and compromising conflict. The major finding of the study was that majority of the head teachers exercise integrating conflict resolution strategies to resolve conflict. Major part of the head teachers adopted obliging conflict resolution strategies to resolve the conflict. Mainstream of head teachers used dominating conflict resolving strategies to resolve conflict. Majority of the head teachers exercise dominating conflict resolving strategies. Greater part of the respondents agreed that head teachers adopted compromising conflict resolving strategies to resolve conflict among staff members. Gender wise comparison indicates that there was a significance difference between male and female head teachers to use the conflict resolution strategies at secondary level.
\end{abstract}

(C) 2021 The authors. Published by SPCRD Global Publishing. This is an open access article under the Creative Commons AttributionNonCommercial 4.0

Corresponding author's email address: masood.ahmad@iub.edu.pk

\section{Introduction}

Now a day center of gravity of human activities is conflict management or conflict resolving strategies. Cheung and Chuah (2000) illustrate that in social relation inevitability of conflict has made 
conflict resolving or conflict management as important component for human survival and adaptability. The reason behind the method adopted to mitigate conflict will decide one's adjustment pattern and survival instinct in terms of how to spend time with people amicably to achieve the predetermine goals. The matter is that live with people friendly call to understand the conflict dynamics and its resolving strategies in a society. There are various conflict resolving strategies one can adopt these conflict resolving strategies in a specific situation. However, it is very crucial to know that these strategies can be used in different situation to resolve conflict among members. Boulding (1998) describes that the nature of emerging conflict, conflict orientation among members, position of conflicting parties and as well as the background of conflict are very important issues, these points will determine the particular conflict resolving strategies.

Faria (2002) define that it is important to keep in mind that conflict will not automatically resolve, if one can use a particular conflict resolving strategy. However, conflict resolving strategy can either resolve the conflict or minimize the conflict or cause conflict to worsen, thus it depend on situation how one can tackle the complex. Thus, whatever result occur, it depend upon the form of conflict resolving strategies adopted on the type of conflict Whitfied (2005) describe that conflict can source a great deal good and or a great deal of injury, depending on conflict resolving strategy of the institution. The main idea behind this, conflict is inevitable, it is suggested that the only this is there should be a meaningful interaction among employees on continuous bases to avoid conflict. Conflict cannot be totally eliminated or cut-off going through this situation. Only the thing that can be done is understand the changing aspect and nature of the conflict to know what can be done for the development and smooth growth of the society. Bloomfield and Reilly (1998) describe that conflict resolution addresses the question in more realistic way; how to bring the opponent side in cooperation process in constructive way, how to handle the practical achievement and cooperative system.

Copley (2008) describes that the main objective of conflict resolution is how to minimize the conflict level where it becomes an optimistic element in social relation and for the development of an organization. Totally, conflict is not a bad thing that should be removed as suggested by the classical theorists. Conflict resolving does not mean to minimize or resolve conflict; it includes designing operational macro-level strategies to reduce the dysfunctions of conflict and improving the productive purposes of conflicts in order to improve learning and efficiency of the institution (Rahim, 2002). Conflict resolving has become an important aspect of organizational development and human relationships as a whole. This is because of the increasing knowledge to increase the teaching learning process to make it efficient, effective and to promote positive interpersonal relationship among society.

The following were the research questions:

1. What type of strategies head teachers' used to resolve conflict among staff members at secondary level?

2. Was there any significance difference between male and female head teachers for conflict resolution strategies?

\section{Literature Review}

Supping and Jing (2006) explain that it is inevitable in social relations that conflict management significantly resonates and conflict cannot be terminated or eliminated in particular situation, but should be positively controlled to get the best results out of this situation. To reduce excessive conflict there may be designed interventions for conflict management or in several examples to growth insufficient conflict. To accomplish the organizational and individual goals, it also contains the diagnosis of and involvement in conflict with the suitable styles and strategies (Gumuselli and 
Hacifazlioglu, 2009). The above definitions indicate that to create positive climate in organizations or institutions that involves the adoption of approaches capable of reducing the volume and intensity of conflict.

Conflict resolution also involves equally increasing the quantities of conflict where it is considered inadequate to persuade the desirable energy to foster progress through creativity and innovation. Conflict resolution is about confirming the existence of a smallest level of conflict to preserve a group "self-critical, viable and creative" (Fuller and Fritzen, 2007). These concepts convey the message that how conflict managed at a particular situation and place either produce functional or dysfunctional. Keeping view this idea, Gumuseli and Hacifazlioglu (2009) defined conflict resolution is a process of minimizing the negative and damaging capacity of conflict through a number of methods through the parties involved in a conflict. The idea of conflict resolution suggests that:

(i) Type of conflicts, may have to reduce, which may have harmful effects on individual and group performance. These conflicts are normally produced by the members i-e (racial disharmony, personal attacks on group members and sexual harassment).

(ii) Another form of conflicts that may perhaps have positive influence on group and as well as individual. Disagreements over tasks, plans, policies and other organization issues, these are also a form of conflict. This form of conflict should be encouraged.

(iii) While interacting with one another the organizational will be essential to deal with their differences positively. This is called a learning point, how to practice diverse conflicthandling strategies to control the numerous conditions efficiently (Rahim, 2002).

The above mention ideas critically discovered the various purposes of conflict resolution, which are as under:

(i) Overwhelming the undesirable belongings of conflict by plummeting its intensity and volume in social interaction.

(ii) Enhancing the optimistic effects of conflict resolution by inspiring such conflict in an institute.

(iii) Encouraging productive or positive methods of handling conflict resolution that may confront the group of people and individuals.

In social relations the continuity of conflict, it is necessary to know about conflict resolution strategies. Smyth (1999) illustrates that it should be necessarily be promoted and taught to people to comprehend the art of handling conflicts. When the individuals are well aware of the numerous conflict resolution strategies and be aware about how and when to use these strategies, they will be able to control the suitable strategy to practice at a specific time. Tonsing (2005) describes that conflict resolution strategies are intended for individual practice at micro-level of social appointment. The usage of these strategies varies from person to person, contextual and situational influences surrounding the existence of conflict. Thomas (1983) illustrates that knowledge, strategies and skills which a person possess on conflict resolution will play critical role to understanding that which of strategy and style to be adopted to address the conflict resolution in positive way. It is very crucial to know that conflict resolution is a set of skills that can be learned by the people for making suitable and appropriate choice of conflict resolution strategies in order to proactively some conflict for optimistic results. Keeping firm command on conflict resolution strategies will aid the fundamental achievement of the person to achieve the goals. (Kahn and Boulding, 1967). 
Truter 2003 indicate that conflict resolution strategies are the styles or approaches that can be exercise to make conflict become harmful management styles are the approaches or strategies that can be employed to make conflict become less harmful for both sides to achieve the goals of the institutions. Time and season often influence the efficiency and performance of the person or institution. There is no best strategy or style to tackle the situation of the institution. This is the reason to know why an efficient conflict resolution strategy is considered as one that should decrease the intensity and volume of conflict to a level tolerable for both groups to attain optimistic change. Vokic and Sontor (2010) describe that conflict resolution strategy is an automatic and habitual approach of answering the conflict with the purpose of attaining predetermined goals of the institution. Practically, every person has a predominant style, but it depends on the surrounding and circumstance of conflict, how to handle the conflict in a particular situation. In this way, there is no single appropriate style to utilize to resolve conflict in all situations. Critical examination of the situation is necessary on the side of both parties to resolve the conflict in positive way.

The human mind is occupied from the ancient age related to issues of conflict and its resolution. Wilmot and Hocket (2011) describe that except for God and love the conflict is a subject that has engaged the thinking of man more than any other issue. At the time of ancient age, they think about conflict that it has actually changed into bulk of ideas on the theme and discussed how conflict can be controlled. Although in 1940 s conflict can be accomplished using conscious efforts and various strategies on development of conflict resolution. Mary Follett was at the first time in the history suggested three main styles of handling conflict, these are: compromise, integration and domination. Later she further added two other styles, these are: suppression and avoidance, in this way she describes the total five conflict resolution styles. Truter (2003) illustrates that the work of Mary Parker Follett marked a change from traditional organization theory of scientific management toward the human relations association and contingency theory.

Smyth (1999) illustrates that two ideas were based on the classification of conflict, an incompatible interaction between two individuals, where one is obstructing, interfering or in other means making the behaviour of another less effective. It was decided that it depend on the consequence of a conflict incident on how the conflict is resolved, either competitively or cooperatively (Deutsch, 1989). The conflict resolution strategies of Deutsch did not gain much acceptance in its practice to define individual's styles of resolving conflicts because disbelief was elevated regarding the capability of the contradiction to reflect, the complication of an individual's observations of conflict behavior. (Putnam and Wilson (1982) describe three strategies to resolve conflicts, which are: avoiding, conquest, and procedural resolution, in addition to reconciliation, compromise and award. Boulding (1998) expired to attention that the development of the institutions' biggest problem is conflict management. Conflict situations are often allowed to progress to almost unmanageable proportions before anything is done about them, in which time is often too late to resolve them by procedural and peaceable and means. It is the need of time and people to deliberately improve knowledge about conflict resolution strategies and develop competence to rightly apply them so as various conflicts early enough before it escalates. Conflict resolution strategies are based on the participation of a third party in conflict resolution range. In view of the ideas of Mary P. Follett (1940), Robert Blake and Jane Mouton in 1964 developed a two element grid, which later changed into five conflict resolution strategies, these are: withdrawing, forcing, compromising, smoothing and problem-solving.

Rahim and Bonoma (1979) describe the idea about conflict resolution strategies and develop a two dimension model of conflict resolution strategies, strategies are grounded on self-concern and concern for others. The self-concern describes the extent to which a person efforts to fulfill his or her 
own concerns or needs, whereas, concern for others is the extent to which a person efforts to fulfill the concerns or needs of others at the expenditure of his/her concern. The grouping of two dimensions carried five scientific conflict resolution strategies, these strategies are: obliging, avoiding, integrating, compromising and dominating. Avoiding strategy is characterized by both low concerns for self and others, whereas obliging strategy indicates low concern for self and high concern for others. Integrating strategy is related to high concerns for self and others; dominating strategy shows high concern for self and low concern for others, whereas compromising strategy is categorized by intermediary concern for self and for others. The figure below shows the conflict resolution strategies of Rahim and Bonoma (1979).

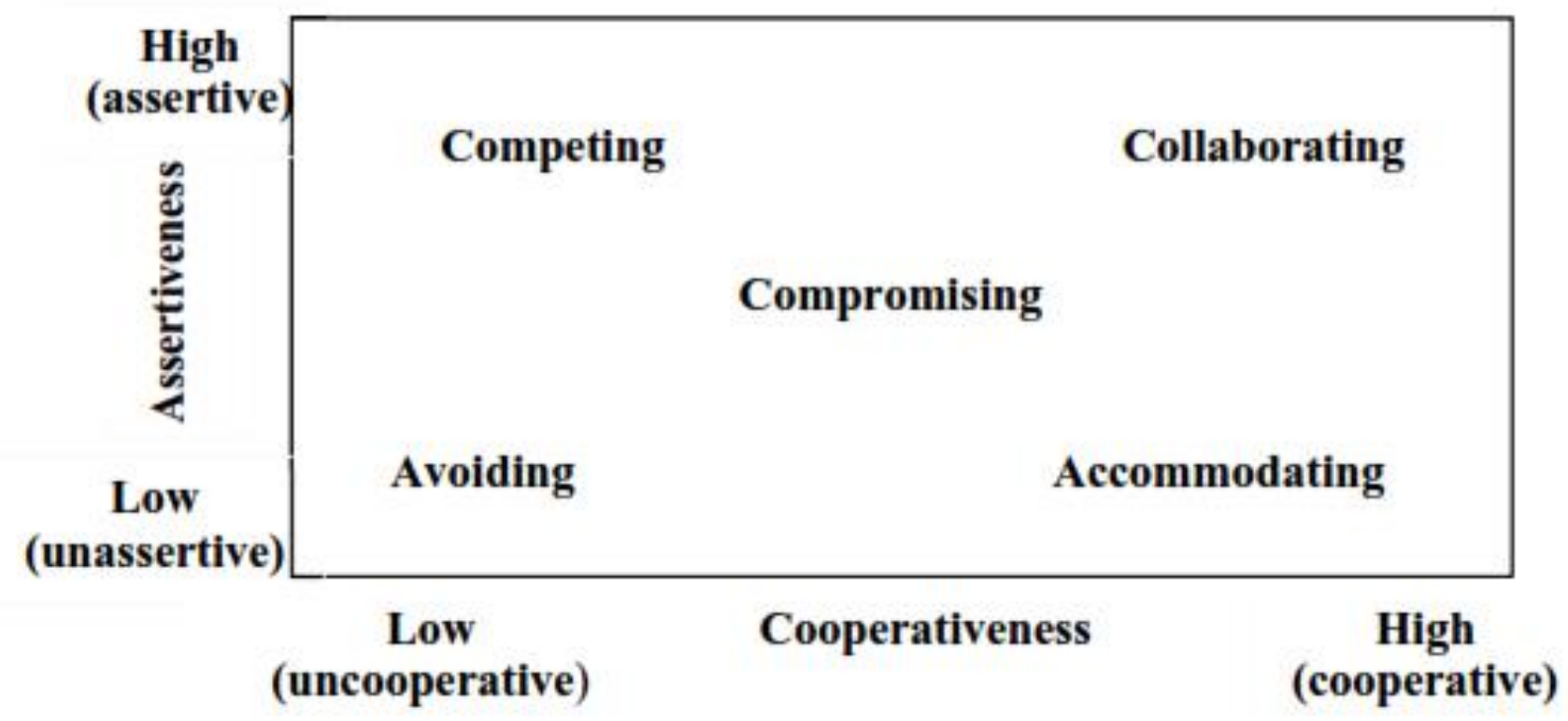

\section{Source: Thomas and Kilmann (1974)}

Figure 1: Rahim-Bonoma Model of Conflict Resolution Strategies

Conflict resolution is a basic component of any organization or institution for its smooth working to achieve the goals. No conflict among employees of can maximize the performance of the organization or institutions. The current study was an attempt to analyze the conflict resolution strategies of the head teachers at secondary level in Bahawalpur, Punjab, Pakistan. The results of this study will be beneficial to maximize the performance of the schools to achieve the goals.

\section{Research Method}

The study designed for head teachers to identify the conflict resolving of the head teachers among staff members at secondary level in Bahawalpur. The study was related to current phenomena so survey method was used for this study. The target population was Bahawalpur district. Bahawalpur district has five tehsil; it was very difficult to collect data from all tehsil of Bahawalpur. So the researcher delimited this study in this way; the study was delimited to only Bahawalpur City and only urban public secondary school of boys and girls were selected as a sample of the study. Sample size was 376 public secondary school teachers, 188 male and 188 female secondary school teachers. 


\section{Development and Validation of Research Instrument}

Literature plays a vital role to conduct study, taking help from literature a questionnaire was designed for secondary school teachers. The questionnaire was designed on four point likert scale (SA, A, D, SD). Five parameters were selected to investigate the conflict resolution strategies of the head teachers. Parameters were integrating conflict, obliging conflict, dominating conflict, avoidance conflict and compromising conflict resolving strategies. Questionnaire was consist of 39 items in which integrating conflict, obliging conflict, dominating conflict and compromising conflict have 8 items each and avoidance conflict has 7 items related to conflict resolution strategies of the head teachers in schools.

Process of validation is necessary to finalize research instruments. To complete this process the instrument were distributed among eight educationists. Experts gave various recommendations; in the light of these recommendations the instrument was modified. Then process of pilot study was started and instrument was distributed twenty secondary school teachers. Reliability of the tool was also ensure, Cronbach coefficient used to calculate reliability. The calculated value of Cronbach coefficient was 0.91, which shows the high reliability of the instrument (Fraenkel, Wallen \& Hyun, 2012).

\section{Data Collection and Analysis}

Questionnaire for public secondary school teachers was used to collect data. It was difficult for researcher to collect all the data personally, so researcher take help from research assistant. Three hundred and seventy six questionnaires were distributed among public secondary school teachers and 362 questionnaires returned back. The response rate of questionnaire was 96\% which was very encouraging for researcher. To analyze data SPSS Ver. 22 was used. To identify the conflict resolution strategies of the head teachers' only percentage was calculated and for gender comparison between male and female t- test of independent samples was applied. The detail of data analysis and findings are as under:

Table 1 indicates teachers' opinions about integrating conflict resolution strategies of head teachers. Teachers opinions show that $79.3 \%$ respondents agreed that head teachers frequently tries to find the issues and make a decision which is acceptable for teachers; $71.6 \%$ respondents agreed that he integrates his opinions with teachers and tries to make a decision collaboratively; $71.3 \%$ teachers agreed that head teachers tries to discuss the problem with teachers to find solution which is according to the expectations of the teachers; 72.9 teachers agreed that he co-ordinate with teachers to make a decision, suitable to all; $80.2 \%$ respondents agreed that he also give his opinion, but he always willing to listen others' opinions; $76.2 \%$ teachers agreed that he always tries to observe conflict on both sides; $84 \%$ teachers agreed that head teachers frequently discussion specific information with other to resolve the problem; $79.9 \%$ respondents agreed that he tries to discuss the problem openly to resolve the issue in best possible way. Overall $76.9 \%$ respondent agreed that head teachers used integrating conflict resolving strategies in schools to smooth running of the school and $23.3 \%$ respondents disagreed that head teachers did not used integrated conflict resolving strategies in schools to resolve the conflict among the staff members. 
Table 1 Teachers' responses about integrating conflict resolution strategies of head teachers

\begin{tabular}{|c|c|c|c|c|c|}
\hline \multirow{2}{*}{$\begin{array}{l}\text { Sr. } \\
\text { No }\end{array}$} & \multirow[t]{2}{*}{ Statements } & \multicolumn{4}{|c|}{ Responses } \\
\hline & & SA & A & $\mathbf{D}$ & SD \\
\hline 1. & $\begin{array}{l}\text { Head teacher frequently tries to find the issues and } \\
\text { make a decision which is acceptable for teachers. }\end{array}$ & $\begin{array}{l}65 \\
17 \cdot 9 \%\end{array}$ & $\begin{array}{l}222 \\
61.4 \%\end{array}$ & $\begin{array}{l}43 \\
11.9 \%\end{array}$ & $\begin{array}{l}32 \\
8.9 \%\end{array}$ \\
\hline 2. & $\begin{array}{l}\text { He integrates his/her opinions with teachers and tries } \\
\text { to make a decision collaboratively. }\end{array}$ & $\begin{array}{l}23 \\
6.4 \%\end{array}$ & $\begin{array}{l}235 \\
64 \cdot 9 \%\end{array}$ & $\begin{array}{l}39 \\
10.8 \%\end{array}$ & $\begin{array}{l}65 \\
18 \%\end{array}$ \\
\hline 3. & $\begin{array}{l}\text { Tries to discuss the problem with teachers to find } \\
\text { solution which is according to the expectations of the } \\
\text { teachers }\end{array}$ & $\begin{array}{l}206 \\
56.9 \%\end{array}$ & $\begin{array}{l}52 \\
14 \cdot 4 \%\end{array}$ & $\begin{array}{l}56 \\
15 \cdot 5 \%\end{array}$ & $\begin{array}{l}48 \\
13 \cdot 3 \%\end{array}$ \\
\hline 4 . & $\begin{array}{l}\text { Co-ordinate with teachers to make a decision, suitable } \\
\text { to all. }\end{array}$ & $\begin{array}{l}175 \\
48 \cdot 3 \%\end{array}$ & $\begin{array}{l}89 \\
24.6 \%\end{array}$ & $\begin{array}{l}75 \\
20.8 \%\end{array}$ & $\begin{array}{l}23 \\
6.4 \%\end{array}$ \\
\hline 5 . & $\begin{array}{l}\text { He also give his opinion, but he always willing to listen } \\
\text { others' opinions. }\end{array}$ & $\begin{array}{l}86 \\
23.8 \%\end{array}$ & $\begin{array}{l}204 \\
56.4 \%\end{array}$ & $\begin{array}{l}59 \\
16.3 \%\end{array}$ & $\begin{array}{l}13 \\
3.6 \%\end{array}$ \\
\hline 6. & He always tries to observe conflict on both sides & $\begin{array}{l}174 \\
48 \%\end{array}$ & $\begin{array}{l}102 \\
28.2 \%\end{array}$ & $\begin{array}{l}23 \\
6.4 \%\end{array}$ & $\begin{array}{l}63 \\
17.4 \%\end{array}$ \\
\hline 7. & $\begin{array}{l}\text { Frequently discussion specific information with other } \\
\text { to resolve the problem }\end{array}$ & $\begin{array}{l}62 \\
17.1 \%\end{array}$ & $\begin{array}{l}242 \\
66.9 \%\end{array}$ & $\begin{array}{l}54 \\
15 \%\end{array}$ & $\begin{array}{l}4 \\
1.1 \%\end{array}$ \\
\hline 8. & $\begin{array}{l}\text { He tries to discuss the problem openly to resolve the } \\
\text { issue in best possible way. }\end{array}$ & $\begin{array}{l}78 \\
21.6 \%\end{array}$ & $\begin{array}{l}211 \\
58.3 \%\end{array}$ & $\begin{array}{l}36 \\
10 \%\end{array}$ & $\begin{array}{l}37 \\
10.2 \%\end{array}$ \\
\hline $\begin{array}{l}\text { Ove } \\
\text { stra }\end{array}$ & $\begin{array}{l}\text { all responses about integrating conflict resolving } \\
\text { egies of head teachers }\end{array}$ & $\begin{array}{l}869 \\
30 \%\end{array}$ & $\begin{array}{l}1357 \\
46.9 \%\end{array}$ & $\begin{array}{l}385 \\
13 \cdot 3 \%\end{array}$ & $\begin{array}{l}285 \\
9 \cdot 9 \%\end{array}$ \\
\hline
\end{tabular}

Table 2 shows teachers' responses about obliging conflict resolving strategies of head teachers. Response rate indicates that $67.5 \%$ teachers agreed that head teacher does not like to rock the boat so he co-operate with others and accept instruction easily; 83.4\% respondents agreed that head teachers co-operate with all who has a good idea; $79.3 \%$ teachers disagreed that head teachers hope to get alone with others than facing an argument; 70.6\% respondents agreed that head teachers takes opinions from others and ready to co-operate with all employees; $68.5 \%$ teachers agreed that head teachers generally focus on his/her priorities to accommodate the need of other people; $63.6 \%$ respondents agreed that he agree early prior to presenting the arguments; $61.6 \%$ teachers agreed that generally does not change opinion but wish to implement decision fully. Overall opinions of the respondents indicate that $57.7 \%$ respondents agreed that head teachers obliged to resolve the conflict so he used conflict resolving strategies in school to resolve the school matters and $44.7 \%$ respondents disagreed that head teachers did not obliged to resolve the conflict among the staff members in schools. 
Table 2: Teachers' responses about obliging conflict resolving strategies of head teachers

\begin{tabular}{|c|c|c|c|c|c|}
\hline \multirow{2}{*}{$\begin{array}{l}\text { Sr. } \\
\text { No }\end{array}$} & \multirow[t]{2}{*}{ Statements } & \multicolumn{4}{|c|}{ Responses } \\
\hline & & SA & A & $\mathbf{D}$ & SD \\
\hline 1. & $\begin{array}{l}\text { Head teacher does not like to rock the boat so he co- } \\
\text { operate with others and accept instruction easily }\end{array}$ & $\begin{array}{l}62 \\
17.1 \%\end{array}$ & $\begin{array}{l}184 \\
50.8 \%\end{array}$ & $\begin{array}{l}71 \\
19.6 \%\end{array}$ & $\begin{array}{l}45 \\
12.4 \%\end{array}$ \\
\hline 2. & He co-operate with all who has a good idea. & $\begin{array}{l}81 \\
22.4 \%\end{array}$ & $\begin{array}{l}221 \\
61 \%\end{array}$ & $\begin{array}{l}36 \\
10 \%\end{array}$ & $\begin{array}{l}105 \\
29 \%\end{array}$ \\
\hline 3. & $\begin{array}{l}\text { He hope to get alone with others than facing an } \\
\text { argument }\end{array}$ & $\begin{array}{l}28 \\
7.7 \%\end{array}$ & $\begin{array}{l}47 \\
13 \%\end{array}$ & $\begin{array}{l}209 \\
57.7 \%\end{array}$ & $\begin{array}{l}78 \\
21.6 \%\end{array}$ \\
\hline 4 . & $\begin{array}{l}\text { Takes opinions from others and ready to co-operate } \\
\text { with all employees. }\end{array}$ & $\begin{array}{l}109 \\
30.1 \%\end{array}$ & $\begin{array}{l}143 \\
39 \cdot 5 \%\end{array}$ & $\begin{array}{l}49 \\
13 \cdot 5 \%\end{array}$ & $\begin{array}{l}61 \\
16.9 \%\end{array}$ \\
\hline 5 . & $\begin{array}{l}\text { Generally focus on his/her priorities to accommodate } \\
\text { the need of other people }\end{array}$ & $\begin{array}{l}69 \\
19 \%\end{array}$ & $\begin{array}{l}179 \\
49 \cdot 5 \%\end{array}$ & $\begin{array}{l}51 \\
14 \%\end{array}$ & $\begin{array}{l}63 \\
17 \cdot 4 \%\end{array}$ \\
\hline 6. & Tries to fulfill the needs of the employees & $\begin{array}{l}101 \\
28 \%\end{array}$ & $\begin{array}{l}129 \\
35.6 \%\end{array}$ & $\begin{array}{l}87 \\
24 \%\end{array}$ & $\begin{array}{l}45 \\
12.4 \%\end{array}$ \\
\hline 7. & Agree early prior to presenting the arguments & $\begin{array}{l}24 \\
6.6 \%\end{array}$ & $\begin{array}{l}81 \\
22.4 \%\end{array}$ & $\begin{array}{l}209 \\
57 \cdot 7 \%\end{array}$ & $\begin{array}{l}48 \\
13 \cdot 3 \%\end{array}$ \\
\hline 8. & $\begin{array}{l}\text { Generally does not change opinion but wish to } \\
\text { implement decision fully }\end{array}$ & $\begin{array}{l}89 \\
24.6 \%\end{array}$ & $\begin{array}{l}134 \\
37 \%\end{array}$ & $\begin{array}{l}99 \\
27 \cdot 4 \%\end{array}$ & $\begin{array}{l}40 \\
11 \%\end{array}$ \\
\hline \multicolumn{2}{|r|}{$\begin{array}{l}\text { Overall responses of the teachers about obliging conflict } \\
\text { resolving strategies of head teachers }\end{array}$} & $\begin{array}{l}563 \\
18.5 \%\end{array}$ & $\begin{array}{l}1118 \\
38.6 \%\end{array}$ & $\begin{array}{l}811 \\
28 \%\end{array}$ & $\begin{array}{l}485 \\
16.7 \%\end{array}$ \\
\hline
\end{tabular}

Table 3 indicates teachers' opinions about dominating conflict resolving strategies of head teachers. Response rate of teachers shows that $71.6 \%$ respondents disagreed that head teacher put influence to get his/her opinion acceptable; $69.3 \%$ teachers disagreed that head teacher put influence of his/her authority to make decision in his/ her favor; 73\% respondents disagreed that head teachers use expertise to make decision in his/her favour; 69.9\% teachers disagreed that head teachers used power to win the competitive situation; 74\% respondents disagreed that head teachers takes opinion once and does not allow having another chance to talk; 67.2\% teachers agreed that when conflict arises head teacher always stand on his/her principles; $88.1 \%$ respondents agreed that head teachers defend his/her decision confidently: 84\% respondents agreed that head teachers generally give arguments in his/her case and insist his point of view on the merit. Overall responses about dominating conflict resolving strategies of head teachers indicate that 51.9\% respondents disagreed that head teachers dominate to resolve the conflict among staff members and $47 \%$ respondents agreed that head teachers used to dominating strategies to resolve the conflict among staff members. 
Table 3: Teachers' opinions about dominating conflict resolving strategies of head teachers

\begin{tabular}{|c|c|c|c|c|c|}
\hline \multirow{2}{*}{$\begin{array}{l}\text { Sr. } \\
\text { No }\end{array}$} & \multirow[t]{2}{*}{ Statements } & \multicolumn{4}{|c|}{ Responses } \\
\hline & & SA & A & $\mathbf{D}$ & SD \\
\hline 1. & $\begin{array}{l}\text { Head teacher put influence to get his/her opinion } \\
\text { acceptable }\end{array}$ & $\begin{array}{l}41 \\
11.3 \%\end{array}$ & $\begin{array}{l}62 \\
17.1 \%\end{array}$ & $\begin{array}{l}206 \\
57 \%\end{array}$ & $\begin{array}{l}53 \\
14.6 \%\end{array}$ \\
\hline 2. & $\begin{array}{l}\text { He put influence of his/her authority to make decision } \\
\text { in his/ her favor }\end{array}$ & $\begin{array}{l}32 \\
8.8 \%\end{array}$ & $\begin{array}{l}79 \\
21.8 \%\end{array}$ & $\begin{array}{l}189 \\
52.2 \%\end{array}$ & $\begin{array}{l}62 \\
17.1 \%\end{array}$ \\
\hline 3. & Expertise use to make decision in his/her favour & $\begin{array}{l}15 \\
4.1 \%\end{array}$ & $\begin{array}{l}86 \\
23.8 \%\end{array}$ & $\begin{array}{l}236 \\
66 \%\end{array}$ & $\begin{array}{l}25 \\
7 \%\end{array}$ \\
\hline 4 . & For competitive situation, he uses power to win it. & $\begin{array}{l}13 \\
4 \%\end{array}$ & $\begin{array}{l}106 \\
29 \cdot 3 \%\end{array}$ & $\begin{array}{l}211 \\
61 \%\end{array}$ & $\begin{array}{l}32 \\
8.9 \%\end{array}$ \\
\hline 5 . & $\begin{array}{l}\text { Once he takes opinion, does not allow having another } \\
\text { chance to talk. }\end{array}$ & $\begin{array}{l}19 \\
5 \cdot 3 \%\end{array}$ & $\begin{array}{l}75 \\
20.7 \%\end{array}$ & $\begin{array}{l}189 \\
52.2 \%\end{array}$ & $\begin{array}{l}79 \\
21.8 \%\end{array}$ \\
\hline 6. & $\begin{array}{l}\text { When conflict arises he generally stand on his/her } \\
\text { principles }\end{array}$ & $\begin{array}{l}65 \\
18 \%\end{array}$ & $\begin{array}{l}178 \\
49.2 \%\end{array}$ & $\begin{array}{l}109 \\
30.1 \%\end{array}$ & $\begin{array}{l}10 \\
2.8 \%\end{array}$ \\
\hline 7. & He defend his/her decision confidently & $\begin{array}{l}76 \\
21 \%\end{array}$ & $\begin{array}{l}243 \\
67.1 \%\end{array}$ & $\begin{array}{l}15 \\
4.1 \%\end{array}$ & $\begin{array}{l}28 \\
7 \cdot 7 \%\end{array}$ \\
\hline 8. & $\begin{array}{l}\text { Generally give arguments in his/her case and insist his } \\
\text { point of view on the merit }\end{array}$ & $\begin{array}{l}26 \\
7.2 \%\end{array}$ & $\begin{array}{l}278 \\
76.8 \%\end{array}$ & $\begin{array}{l}45 \\
12.4 \%\end{array}$ & $\begin{array}{l}13 \\
3.6 \%\end{array}$ \\
\hline \multicolumn{2}{|r|}{$\begin{array}{l}\text { Overall responses of the teachers about dominating conflict } \\
\text { resolving strategies of head teachers }\end{array}$} & $\begin{array}{l}246 \\
8.5 \%\end{array}$ & $\begin{array}{l}1107 \\
38.5 \%\end{array}$ & $\begin{array}{l}1200 \\
41.4 \%\end{array}$ & $\begin{array}{l}302 \\
10.5 \%\end{array}$ \\
\hline
\end{tabular}

Table 4 indicates teachers' opinions about avoiding conflict resolving strategies of head teachers. Response rate of teachers shows that $71.6 \%$ respondents disagreed that head teacher put influence to get his/her opinion acceptable; 69.3\% teachers disagreed that head teacher put influence of his/her authority to make decision in his/ her favor; 73\% respondents disagreed that head teachers use expertise to make decision in his/her favour; 69.9\% teachers disagreed that head teachers used power to win the competitive situation; $74 \%$ respondents disagreed that head teachers takes opinion once and does not allow having another chance to talk; 67.2\% teachers agreed that when conflict arises head teacher always stand on his/her principles; $88.1 \%$ respondents agreed that head teachers defend his/her decision confidently: $84 \%$ respondents agreed that head teachers generally give arguments in his/her case and insist his point of view on the merit. Overall responses about avoiding conflict resolving strategies of head teachers indicate that $51.9 \%$ respondents disagreed that head teachers avoid resolving the conflict among staff members and $47 \%$ respondents agreed that head teachers used to avoiding strategies to resolve the conflict among staff members. 
Table 4: Teachers' responses about avoidance conflict resolving strategies of head teachers

\begin{tabular}{|c|c|c|c|c|c|}
\hline \multirow{2}{*}{$\begin{array}{l}\text { Sr. } \\
\text { No }\end{array}$} & \multirow[t]{2}{*}{ Statements } & \multicolumn{4}{|c|}{ Responses } \\
\hline & & SA & A & $\mathbf{D}$ & SD \\
\hline 1. & $\begin{array}{l}\text { Difference of opinions is not worth worrying for him, } \\
\text { so he generally ignores it. }\end{array}$ & $\begin{array}{l}23 \\
6.4 \%\end{array}$ & $\begin{array}{l}89 \\
24.6 \%\end{array}$ & $\begin{array}{l}192 \\
53 \%\end{array}$ & $\begin{array}{l}58 \\
16 \%\end{array}$ \\
\hline 2. & $\begin{array}{l}\text { When conflict arises he does not do anything tend to } \\
\text { back out of the situation }\end{array}$ & $\begin{array}{l}72 \\
20 \%\end{array}$ & $\begin{array}{l}182 \\
50.3 \%\end{array}$ & $\begin{array}{l}93 \\
25 \cdot 7 \%\end{array}$ & $\begin{array}{l}15 \\
4.1 \%\end{array}$ \\
\hline 3. & $\begin{array}{l}\text { Who have strong opinions head teacher tries to ignore } \\
\text { them }\end{array}$ & $\begin{array}{l}11 \\
3 \%\end{array}$ & $\begin{array}{l}86 \\
23.8 \%\end{array}$ & $\begin{array}{l}194 \\
54 \%\end{array}$ & $\begin{array}{l}71 \\
19.6 \%\end{array}$ \\
\hline 4 . & He generally tries to avoid quarrelsome employees & $\begin{array}{l}132 \\
36.5 \%\end{array}$ & $\begin{array}{l}95 \\
26.2 \%\end{array}$ & $\begin{array}{l}53 \\
14.6 \%\end{array}$ & $\begin{array}{l}82 \\
22.7 \%\end{array}$ \\
\hline 5 . & Head teacher tries to avoid manage conflict & $\begin{array}{l}36 \\
10 \%\end{array}$ & $\begin{array}{l}72 \\
20 \%\end{array}$ & $\begin{array}{l}136 \\
37.6 \%\end{array}$ & $\begin{array}{l}118 \\
32.6 \%\end{array}$ \\
\hline 6. & He desire to refrain than to retreat from a quarrel & $\begin{array}{l}83 \\
22.9 \%\end{array}$ & $\begin{array}{l}146 \\
40.3 \%\end{array}$ & $\begin{array}{l}102 \\
28.1 \%\end{array}$ & $\begin{array}{l}31 \\
8.6 \%\end{array}$ \\
\hline 7. & When conflict arise he generally avoid harsh attitude. & $\begin{array}{l}56 \\
15.4 \%\end{array}$ & $\begin{array}{l}162 \\
44.8 \%\end{array}$ & $\begin{array}{l}95 \\
26.2 \%\end{array}$ & $\begin{array}{l}49 \\
13.5 \%\end{array}$ \\
\hline \multicolumn{2}{|r|}{$\begin{array}{l}\text { Overall responses of the teachers about avoidance conflict } \\
\text { resolving strategies of head teachers }\end{array}$} & $\begin{array}{l}422 \\
16.7 \%\end{array}$ & $\begin{array}{l}832 \\
32.9 \%\end{array}$ & $\begin{array}{l}865 \\
34.1 \%\end{array}$ & $\begin{array}{l}424 \\
16.8 \%\end{array}$ \\
\hline
\end{tabular}

Table 5 indicates teacher's opinions about compromising conflict resolving strategies of head teachers. Response rate shows that $61.8 \%$ teachers agreed that head teachers tries to suggest a middle ground, when different viewpoints came in same matte; $74.1 \%$ respondents disagreed that whenever there is disagreement head teachers likes to meet the employees half-way; $77.3 \%$ teachers agreed that when conflict arise, head teachers tries to compromise to tackle the situation; $56.6 \%$ respondents agreed that head teachers tries to decide the solution of the problem a middle ground rather to satisfying completely; 59.3\% teachers agreed that head teachers wished to be half-wrong rather than discover difference in conflict; 74.5\% respondents agreed that to meet other employees' need, head teachers generally slightly modify his goals; $69.3 \%$ teachers agreed that head teacher usually willing to modify the priorities to reach the solution, when conflict arises; 90.8\% respondents agreed that head teachers just to move on, they prefer to solve the problem by compromising. Overall response rate about compromising conflict resolving strategies of head teachers shows that $64.6 \%$ respondents agreed that head teachers compromise to resolve the conflict among staff members and $35.4 \%$ respondents disagreed that head teachers did not compromise to resolve the conflict among the staff members. 
Table 5: Teachers view about compromising conflict resolving strategies of head teachers

\begin{tabular}{|c|c|c|c|c|c|}
\hline \multirow{2}{*}{$\begin{array}{l}\text { Sr. } \\
\text { No }\end{array}$} & \multirow[t]{2}{*}{ Statements } & \multicolumn{4}{|c|}{ Responses } \\
\hline & & SA & A & D & SD \\
\hline 1. & $\begin{array}{l}\text { He tries to suggest a middle ground, when different } \\
\text { viewpoints came in same matter }\end{array}$ & $\begin{array}{l}28 \\
7 \cdot 7 \%\end{array}$ & $\begin{array}{l}196 \\
54.1 \%\end{array}$ & $\begin{array}{l}87 \\
24 \%\end{array}$ & $\begin{array}{l}51 \\
14 \%\end{array}$ \\
\hline 2. & $\begin{array}{l}\text { Whenever there is disagreement he likes to meet the } \\
\text { employees half-way }\end{array}$ & $\begin{array}{l}15 \\
4.1 \%\end{array}$ & $\begin{array}{l}79 \\
21.8 \%\end{array}$ & $\begin{array}{l}214 \\
59.1 \%\end{array}$ & $\begin{array}{l}54 \\
15 \%\end{array}$ \\
\hline 3. & $\begin{array}{l}\text { When conflict arise, he/she tries to compromise to } \\
\text { tackle the situation }\end{array}$ & $\begin{array}{l}98 \\
27 \%\end{array}$ & $\begin{array}{l}182 \\
50.3 \%\end{array}$ & $\begin{array}{l}74 \\
20.4 \%\end{array}$ & $\begin{array}{l}08 \\
2.2 \%\end{array}$ \\
\hline 4. & $\begin{array}{l}\text { Tries to decide the solution of the problem a middle } \\
\text { ground rather to satisfying completely }\end{array}$ & $\begin{array}{l}108 \\
29.8 \%\end{array}$ & $\begin{array}{l}97 \\
26.8 \%\end{array}$ & $\begin{array}{l}82 \\
22.7 \%\end{array}$ & $\begin{array}{l}75 \\
20.7 \%\end{array}$ \\
\hline 5. & $\begin{array}{l}\text { Wished to be half-wrong rather than discover } \\
\text { difference in conflict. }\end{array}$ & $\begin{array}{l}62 \\
17.1 \%\end{array}$ & $\begin{array}{l}153 \\
42.2 \%\end{array}$ & $\begin{array}{l}55 \\
15.2 \%\end{array}$ & $\begin{array}{l}92 \\
25 \cdot 4 \%\end{array}$ \\
\hline 6. & $\begin{array}{l}\text { To meet other employees' need, he generally slightly } \\
\text { modify his goals }\end{array}$ & $\begin{array}{l}98 \\
27 \%\end{array}$ & $\begin{array}{l}172 \\
47 \cdot 5 \%\end{array}$ & $\begin{array}{l}56 \\
15 \cdot 5 \%\end{array}$ & $\begin{array}{l}36 \\
9 \cdot 9 \%\end{array}$ \\
\hline 7. & $\begin{array}{l}\text { Usually head teacher willing to modify the priorities to } \\
\text { reach the solution, when conflict arises }\end{array}$ & $\begin{array}{l}109 \\
30.1 \%\end{array}$ & $\begin{array}{l}142 \\
39.2 \%\end{array}$ & $\begin{array}{l}81 \\
22.4 \%\end{array}$ & $\begin{array}{l}30 \\
8.3 \%\end{array}$ \\
\hline 8. & $\begin{array}{l}\text { Just to move on, he prefer to solve the problem by } \\
\text { compromising }\end{array}$ & $\begin{array}{l}95 \\
26.2 \%\end{array}$ & $\begin{array}{l}234 \\
64.6 \%\end{array}$ & $\begin{array}{l}19 \\
5.2 \%\end{array}$ & $\begin{array}{l}14 \\
3 \cdot 9 \%\end{array}$ \\
\hline \multicolumn{2}{|r|}{$\begin{array}{l}\text { Overall responses of the teachers about compromising } \\
\text { conflict resolving strategies of head teachers. }\end{array}$} & $\begin{array}{l}613 \\
21.2 \%\end{array}$ & $\begin{array}{l}1255 \\
43 \cdot 4 \%\end{array}$ & $\begin{array}{l}668 \\
23 \%\end{array}$ & $\begin{array}{l}360 \\
12.4 \%\end{array}$ \\
\hline
\end{tabular}

Table 6 describes the gender wise comparison of teachers' responses about conflict resolution strategies of head teachers at public secondary schools. Conflict resolution strategies adopted by the head teachers at secondary level show that there was a significance difference between the opinion of male and female teachers $(t=-9.42, \mathrm{p}<0.05)$. Mean score of female teachers (3.85) was significantly higher than the male (3.39). It indicates that female head teachers were controlled conflict in better way as compared to male head teachers, in another way that female head teachers used more conflict resolution strategies as compare to male head teachers at public secondary schools in Bahawalpur, Punjab, Pakistan.

Table 6 Gender wise comparison of teachers' opinions about conflict resolution strategies of the head teachers at public secondary schools

\begin{tabular}{|l|l|l|l|l|l|l|}
\hline Variables & Gender & $\mathbf{N}$ & $\begin{array}{l}\text { Mean } \\
\text { Score }\end{array}$ & SD & t-value & p-value \\
\hline \multirow{2}{*}{ Conflict Resolution Strategies } & Male & 362 & 3.39 & 0.62 & \multirow{2}{*}{$0.00^{*}$} \\
\cline { 2 - 6 } & Female & 362 & 3.85 & 0.40 & -9.42 & \multirow{2}{*}{0.42} \\
\hline
\end{tabular}

*Significant $\mathrm{P}<0.05$ 


\section{Findings and Discussions}

The purpose of the study was to analyze the conflict resolution strategies of head teachers at public secondary schools. The findings of the study related to integrating conflict resolution strategies of the head teachers indicate that 79.3\% respondents agreed that head teachers frequently tries to find the issues and make a decision which is acceptable for teachers; $71.6 \%$ respondents agreed that he integrates his opinions with teachers and tries to make a decision collaboratively; $71.3 \%$ teachers agreed that head teachers tries to discuss the problem with teachers to find solution which is according to the expectations of the teachers; 72.9 teachers agreed that he co-ordinate with teachers to make a decision, suitable to all; $80.2 \%$ respondents agreed that he also give his opinion, but he always willing to listen others' opinions; $76.2 \%$ teachers agreed that he always tries to observe conflict on both sides; $84 \%$ teachers agreed that head teachers frequently discussion specific information with other to resolve the problem; $79.9 \%$ respondents agreed that he tries to discuss the problem openly to resolve the issue in best possible way. Overall $76.9 \%$ respondent agreed that head teachers used integrating conflict resolving strategies in schools to smooth running of the school and $23.3 \%$ respondents disagreed that head teachers did not used integrated conflict resolving strategies in schools to resolve the conflict among the staff members. Copley (2008) conducted study on conflict management styles: A predictor of likability and perceived effectiveness among subordinates in Indian University. The study concluded that integrating conflict resolving strategy is the best way to resolve the conflict among the members of the organization. Another study was conducted by Connelly (1998) on conflict management styles of a selected group of Pennsylvania superintendents' and their board presidents' perceptions of their conflict management styles. The study also concluded that integrating conflict resolving style the good techniques to minimize the conflict situation.

The findings concerning to obliging conflict resolving strategies of head teachers show that $67.5 \%$ teachers agreed that head teacher does not like to rock the boat so he co-operate with others and accept instruction easily; $83.4 \%$ respondents agreed that head teachers co-operate with all who has a good idea; $79.3 \%$ teachers disagreed that head teachers hope to get alone with others than facing an argument; $70.6 \%$ respondents agreed that head teachers takes opinions from others and ready to cooperate with all employees; $68.5 \%$ teachers agreed that head teachers generally focus on his/her priorities to accommodate the need of other people; $63.6 \%$ respondents agreed that he agree early prior to presenting the arguments; $61.6 \%$ teachers agreed that generally does not change opinion but wish to implement decision fully. Overall opinions of the respondents indicate that $57.7 \%$ respondents agreed that head teachers obliged to resolve the conflict so he used conflict resolving strategies in school to resolve the school matters and $44.7 \%$ respondents disagreed that head teachers did not obliged to resolve the conflict among the staff members in schools. Faria (2002) designed study on an investigative analysis of conflict management theory and practice as examined from the operative position of the secondary school assistant principalship. The study was based on purely on conflict management theory and practice. The find out that principal obliged to resolve the conflict and integrating conflict resolving strategies.

The finding about dominating conflict resolving strategies of head teachers shows that $71.6 \%$ respondents disagreed that head teacher put influence to get his/her opinion acceptable; 69.3\% teachers disagreed that head teacher put influence of his/her authority to make decision in his/ her favor; $73 \%$ respondents disagreed that head teachers use expertise to make decision in his/her favour; $69.9 \%$ teachers disagreed that head teachers used power to win the competitive situation; $74 \%$ respondents disagreed that head teachers takes opinion once and does not allow having another chance to talk; $67.2 \%$ teachers agreed that when conflict arises head teacher always stand on his/her principles; 88.1\% respondents agreed that head teachers defend his/her decision confidently: $84 \%$ 
respondents agreed that head teachers generally give arguments in his/her case and insist his point of view on the merit. Overall responses about dominating conflict resolving strategies of head teachers indicate that $51.9 \%$ respondents disagreed that head teachers dominate to resolve the conflict among staff members and $47 \%$ respondents agreed that head teachers used to dominating strategies to resolve the conflict among staff members. Folger, Poole and Stutman (1997) conducted study at New York on working through conflict: strategies for relationships, groups, and organization. The findings of the study shows that leader of the organization cannot resolve the conflict by using the dominating conflict resolving strategies at work place to achieve the organizational goals.

The finding related to avoiding conflict resolving strategies of head teachers show that $71.6 \%$ respondents disagreed that head teacher put influence to get his/her opinion acceptable; 69.3\% teachers disagreed that head teacher put influence of his/her authority to make decision in his/ her favor; $73 \%$ respondents disagreed that head teachers use expertise to make decision in his/her favour; $69.9 \%$ teachers disagreed that head teachers used power to win the competitive situation; $74 \%$ respondents disagreed that head teachers takes opinion once and does not allow having another chance to talk; $67.2 \%$ teachers agreed that when conflict arises head teacher always stand on his/her principles; $88.1 \%$ respondents agreed that head teachers defend his/her decision confidently: $84 \%$ respondents agreed that head teachers generally give arguments in his/her case and insist his point of view on the merit. Overall responses about avoiding conflict resolving strategies of head teachers indicate that $51.9 \%$ respondents disagreed that head teachers avoid resolving the conflict among staff members and $47 \%$ respondents agreed that head teachers used to avoiding strategies to resolve the conflict among staff members. Gumuseli and Hacifazlioglu (2009) conducted study on globalization and conflict management in schools. The results of the study also in favour of this study and show that school head cannot used avoiding conflict resolving strategies in schools. Avoid the situation can create other problems for administration.

The finding about compromising conflict resolving strategies of head teachers shows that $61.8 \%$ teachers agreed that head teachers tries to suggest a middle ground, when different viewpoints came in same matte; $74.1 \%$ respondents disagreed that whenever there is disagreement head teachers likes to meet the employees half-way; 77.3\% teachers agreed that when conflict arise, head teachers tries to compromise to tackle the situation; 56.6\% respondents agreed that head teachers tries to decide the solution of the problem a middle ground rather to satisfying completely; $59.3 \%$ teachers agreed that head teachers wished to be half-wrong rather than discover difference in conflict; $74.5 \%$ respondents agreed that to meet other employees' need, head teachers generally slightly modify his goals; 69.3\% teachers agreed that head teacher usually willing to modify the priorities to reach the solution, when conflict arises; 90.8\% respondents agreed that head teachers just to move on, they prefer to solve the problem by compromising. Overall response rate about compromising conflict resolving strategies of head teachers shows that $64.6 \%$ respondents agreed that head teachers compromise to resolve the conflict among staff members and 35.4\% respondents disagreed that head teachers did not compromise to resolve the conflict among the staff members. Knudson, Sommers and Golding (1980) designed study on interpersonal perception and mode of resolution in marital conflict. One aspect of this study support the finding of this study and indicate that to resolve the conflict among members and group of members is the best techniques that compromise the situation and try to solve the problems to achieve the goals. Literature also supports the findings of this study. Ojiji (2006) describes in conflict handling styles that to control conflict in better way one should be used conflict resolving strategies i-e integrating conflict, dominating conflict, avoiding conflict and compromising conflict resolving strategies. 
Finding related to gender comparison show that there was a significance difference between the opinion of male and female teachers $(t=-9.42, \mathrm{p}<0.05)$. Mean score of female teachers (3.85) was significantly higher than the male (3.39). It indicates that female head teachers were controlled conflict in better way as compared to male head teachers at public secondary schools in Bahawalpur, Punjab, Pakistan. Chusmir and Mills (1989) conducted study on gender differences in conflict resolution styles of managers: at work and at Home. The finding of the study also in favour of this study and show that female manager used more conflict resolving styles at compare to male managers. It is also a worth valuing that the finding of the study match the results of international conducted study. Papa and Natalle (1989) conducted study on gender, strategy selection and satisfaction in interpersonal conflict. The findings of this study show that there was a significance difference between the mean score of male and female, mean score of female was significantly higher than the mean score of male. The results of this research also support the finding of current study.

\section{Conclusions}

The study has concluded that majority of the head teachers exercise integrating conflict resolution strategies when conflict arises among staff members in schools. Major part of the head teachers in schools adopted obliging conflict resolution strategies to resolve the conflict among the employees of the schools. Mainstream of the head teachers used dominating conflict resolving strategies in schools to resolve the conflict among staff members at secondary level. Majority of the head teachers exercise dominating conflict resolving strategies in institutions to minimize conflict among staff members. Greater part of the respondents agreed that head teachers adopted compromising conflict resolving strategies in schools to resolve conflict among staff members. Gender wise comparison of male and female head teachers about the use of conflict resolution strategies indicate that there was a significance difference between male and female head teachers to use the conflict resolution strategies at secondary level. Mean score of female head teachers was significantly higher than the mean score of male head teachers. Its mean female head teachers were used more strategies to control the conflict among the staff member as compared to male head teachers in schools at secondary level in Bahawalpur, Punjab, Pakistan.

\section{Recommendations}

It is clear from the historical perspective that conflict is inevitable among human being. But, the strategies adopted to resolve the conflict is matter a lot. So, conflict consequence can either be positive or negative, it depends on the type of conflict resolution strategies used to resolve the conflict. The implementation of conflict resolving strategies should not be prompt without due deliberation of the nature of conflict, circumstances surrounding the conflict and parties involved in it. Before adaptation of a particular conflict resolution strategy, the dynamic nature of a conflict and attitudes of conflicting parties should be carefully analyzed and understood. The conflict resolution strategies are effect by dispositional and situational factors also. So, the usefulness of strategies is the purpose of some salient elements which have been explored in this study.

\section{References}

Bloomflied, D. and Reilly, B. (1998). The changing nature of conflict and conflict management. Democracy and deep-rooted conflict: option for negotiators. P.Harris, and B. Reilly.Eds. Stockholm: Institute for Democracy and Electoral Assistance (IDEA).

Boulding, K.E. (1998). Conflict and defense: a general theory. New York: Harper Torchbooks; Harper and Row Publishers.

Cheung, C.C. and Chuah, K. B. (2000). Intergroup conflict management framework for Hong Kong's 
manufacturing industry. Engineering Management Journal 12.3:26-33.

Chusmir, L. H. and Mills, J. (1989). Gender differences in conflict resolution styles of managers: at work and at Home. Sex Roles 20.3-4:149-163.

Connelly, Jr. L.R .(1998). Conflict management styles of a selected group of Pennsylvania superintendents' and their board presidents' perceptions of their conflict management styles. Ph.D. Thesis. School of Graduate Studies, Youngstown State University, U.S.A.

Copley, R. D. (2008). Conflict management styles: A predictor of likability and perceived effectiveness among subordinates. M. A. Dissertation. Department of Communication Studies, Indiana University.

Faria, R.G. (2002). An investigative analysis of conflict management theory and practice as examined from the operative position of the secondary school assistant principalship. Boston: Boston College School of Education.

Folger. J. P., Poole, M. S. and Stutman, R.K (1997). Working through conflict: strategies for relationships, groups, and organization. New York: Harper Collins.

Fraenkel, J.R., Wallen, N.E. \& Hyun, H. H. (2012). How to Design and Research in Education. (8th ed.) New York: McGraHill.

Fuller, B.W. and Fritzen, S.A. (2007). Negotiation and conflict management: a public policy perspective. Lee Kuan Yew School of Public Policy. National University of Singapore.

Gumuseli, A. I. and Hacifazlioglu, O. (2009). Globalization and conflict management in schools. Cypriot Journal of Educational Sciences 4: 183-198.

Kahn, R. L; and Boulding, E. (1967). Power and conflict in organisation. New York: Basic Books, Inc.

Knudson, R.M. Sommers, A.A. and Golding, S.L. (1980). Interpersonal perception and mode of resolution in marital conflict. Journal of Personality and Social Psychology 38:751-763.

Ojiji, O. (2006). Conflict handling styles. Introduction to peace and conflict studies in West Africa S.G. Best Ed. Ibadan: Spectrum Books Limited.

Papa, M. J. and Natalle, E.J. (1989). Gender, strategy selection and satisfaction in interpersonal conflict. Western Journal of Speech Communication 53:260-272.

Putnam, L. and Wilson, C. (1982). Communicative strategies in organizational conflict: rehability and validity of measurement scale. Communication Yearbook. M. Burgoon, Ed. Newbury Park, CA: Sage.

Rahim, M. A. (2002). Towards a theory of managing organizational conflict. International Journal of Conflict Management 13. 3:368-376.

Supping, T. and Jing, W. (2006). Interpersonal conflict handling styles: a survey of Chinese College Students. Canadian Social 2. 3:44-53.

Thomas, K.W. (1983). Conflict and conflict management. Handbook in Industrial and Organizational Psychology. M. D. Dunnette. Ed. New York: John Wiley.

Tonsing, J.T. (2005). Conflict in organization. Mumbai: Better Yourself Books.

Truter, I. (2003). Conflict. South African Pharmaceutical Journal 70. 5:5.

Vokic, N.P. and Sontor, S. (2010). The relationship between individual characteristics and conflict handling styles. The case of Croatia. Problem and Perspective in Management 8.3:56-67.

Whitfied, J. (2005). Conflicts in Construction: Avoiding, Managing, Resolving. New York: Macmillian

Wilmot,W.W.and Hocket,J.(2011). Interpersonal Conflict. New York: McGraw-Hill 